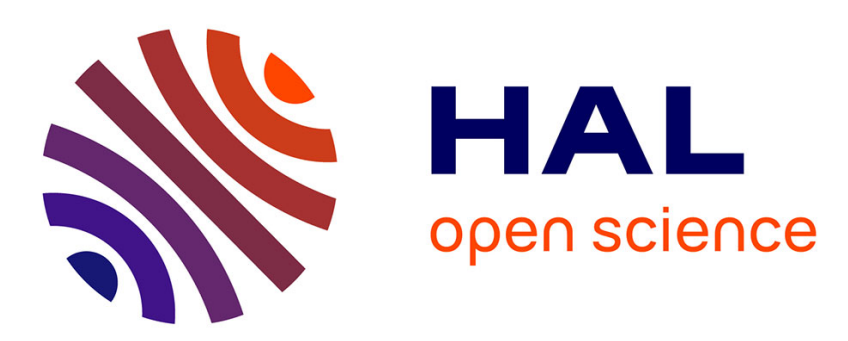

\title{
Simulation of human exposure to benzylpenicillin residues via pork originating from pigs fed with a dairy by-product
}

\author{
Ulla Maria Karlström, Lasse Nuotio, Erja Lindfors, Riitta Maijala
}

\section{To cite this version:}

Ulla Maria Karlström, Lasse Nuotio, Erja Lindfors, Riitta Maijala. Simulation of human exposure to benzylpenicillin residues via pork originating from pigs fed with a dairy by-product. Food Additives and Contaminants, 2007, 24 (03), pp.266-273. 10.1080/02652030601039005 . hal-00577518

\author{
HAL Id: hal-00577518 \\ https://hal.science/hal-00577518
}

Submitted on 17 Mar 2011

HAL is a multi-disciplinary open access archive for the deposit and dissemination of scientific research documents, whether they are published or not. The documents may come from teaching and research institutions in France or abroad, or from public or private research centers.
L'archive ouverte pluridisciplinaire $\mathbf{H A L}$, est destinée au dépôt et à la diffusion de documents scientifiques de niveau recherche, publiés ou non, émanant des établissements d'enseignement et de recherche français ou étrangers, des laboratoires publics ou privés. 


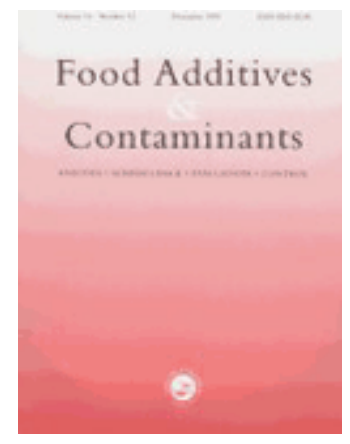

\section{Simulation of human exposure to benzylpenicillin residues via pork originating from pigs fed with a dairy by-product}

\begin{tabular}{|r|l|}
\hline Journal: & Food Additives and Contaminants \\
\hline Manuscript ID: & TFAC-2006-047.R1 \\
\hline Manuscript Type: & Original Research Paper \\
\hline Author: & 23-Sep-2006 \\
\hline Complete List of Authors: & $\begin{array}{l}\text { Karlström, Ulla; National Veterinary and Food Research Institute, } \\
\text { EELA, Risk Assessment } \\
\text { Nuotio, Lasse; National Veterinary and Food Research Institute, } \\
\text { EELA, Risk Assessment } \\
\text { Lindfors, Erja; National Veterinary and Food Research Institute, } \\
\text { EELA, Chemistry } \\
\text { Maijala, Riitta; National Veterinary and Food Research Institute, } \\
\text { EELA, Risk Assessment; University of Helsinki, Food and } \\
\text { Environmental Hygiene }\end{array}$ \\
\hline Methods/Techniques: & $\begin{array}{l}\text { Exposure assessment, HPLC, Probabalistic modelling, Risk } \\
\text { assessment }\end{array}$ \\
\hline Additives/Contaminants: & Veterinary drug residues - antimicrobials \\
\hline Food Types: & Animal feed, Animal products - meat \\
\hline & \\
\hline
\end{tabular}

\section{SCHOLARONE Manuscripts}




\section{Simulation of human exposure to benzylpenicillin residues via pork originating from pigs fed with a dairy by-product}

Ulla Karlstrom, Lasse Nuotio, Erja Lindfors and Ritta Maijala

National Veterinary and Food Research Institute, EELA - Risk Assessment BO Box 45, Helsinki 00581 (Finland)

The use of food industry by-products for feeding is restricted by the European Union (EU) by-product regulation (1774/2002). However, the actual public health risks involved in the use of such products are poorly recognized. This study focuses on bovine milk rejected at the dairy because of a positive result in antimicrobial drug testing and thereafter used as feed for finisher pigs in Finland. In theory, this current practice could expose pork consumers to antimicrobial drug residues. Raw bulk milk samples originating from rejected lots were analysed with a multi-residue method detecting five betalactams, including benzylpenicillin (BP). Based on the probabilistic simulation model developed, concentrations of BP in pork invariably remained below $1 \%$ of the maximum residue limit (MRL). Therefore the use of this by-product as feed with the current practice was considered to pose only a negligible risk to consumers of pork products.

Keywords: By-product, feed, antimicrobial drug residues, benzylpenicillin, pork, simulation model, exposure assessment, risk assessment, Finland 


\section{Introduction}

The food industry produces extensive amounts of various by-products, many of which serve as animal feed. For example, in 2004, the dairy industry in Finland dispensed over 140000 tons of by-products for feeding, most of which, $82 \%$, consisted of whey and whey concentrate (National Food Administration [NFA] 2005).The new EU regulation on animal by-products (1774/2002) limits the use of such biomaterial as an animal feed, and member states must either ascertain the safety of such products as animal feed, or come up with sustainable solutions on how to dispose of these products (European Union [EU] 2002).

This precautionary approach is justified, e.g. BSE is generally believed to have spread by the recycling of the proteinaceous material from the carcases of infected cattle into meat and bone meal. This permitted the amplification of what was previously a very rare cattle disease (Anderson et al. 1996, Wilesmith et al. 1988). However, many animal by-products have a high nutritional value and most likely do not pose any significant risks when used as feed. Only a few studies have evaluated the risks imposed by such products.

Finnish national legislation (Ministry of agriculture and forestry [MMM] 2001) demands that each raw milk lot arriving at dairy must be tested with a microbiological screening test for antimicrobial drug residues. National testing statistics indicate that antimicrobial drug residues are detected in $0.05 \%$ of milk lots (Finnish Association for Milk Hygiene [FAM] 2005). The most common residue is benzylpenicillin (BP), ensuing from treatment of cows for mastitis. Commercially available microbiological screening tests are very sensitive for 
this antimicrobial substance and usually detect BP at its MRL $\left(4 \mu \mathrm{gg}^{-1}\right)$ (European Medicines Agency [EMEA] 2005a). The efficient testing practice in Finland ensures safe milk products for consumers and reduces problems in cheese production.

Milk rejected for human consumption is used, after mixing with other ingredients, as feed for finisher pigs. This long-standing practise is at odds with the new EU by-products regulation. In theory, such a practice has the potential to lead to BP residues in pork and indirectly expose consumers to the residues. A total exposure of as negligible as $3 \mu \mathrm{g}$ of $\mathrm{BP}$ has been reported to elicit allergic reactions, such as rash or urticaria, in individuals previously sensitized to penicillin (Borrie and Barret 1961, Dewdney et al. 1991).

The occurrence of test positive milk loads in Finland is a rare (ca 50 annually) and random event. Timely tracing of the farms receiving the rejected lots and representative sampling of the prepared feed, as well as reliable sampling and determination of the residue level in retail pork, were considered infeasible. The objective of this study was to construct a probabilistic dilution and exposure model for the residue, starting from the rejected milk and arriving to the concentration in pork. The aim was to assess the safety of the long-standing feeding practice to consumers by comparing the modelled probable distribution of $\mathrm{BP}$ residue concentration in pork with the appropriate Maximum Residue Limit (MRL) -value (European Community [EC] 1990; EMEA 2005a).

\section{Materials and methods}


Data about the amounts of milk containing antimicrobial drug residues rejected at dairies and the amount of other dairy by-products mixed with the milk prior to the delivery to the pig farms were obtained from the National Food Agency. The data about the feed processing practices on the farms, consumption data and the duration of the time when milk was used on farms were obtained from the Plant Production Inspection Centre. In addition, laboratory analyses were carried out to obtain information on the BP concentrations in the rejected bulk milk lots. Since no data on the concentration of BP in the final feed mixture were available, a simulation model was developed to estimate the daily exposures of fattening pigs and thereafter the amount of BP residues in pork meat.

Other parameters taken into consideration in the simulation model were the, oral bioavailability and metabolism of BP. Based on literature, benzylpenicillin is not chemically stable at the low pH present in the stomach. The gastric acid hydrolyses the beta-lactam ring and only a minor proportion, 15-30\%, of the orally ingested BP dose is bioavailable (Plumb 1991). Additionally, the half-life of BP in serum is comparatively short, 1.7 hours (Luthman et al. 1988). These parameters that reduce the possible amount of residues in pork meat were included into the evaluation (see Figure 1).

[insert Figure 1 about here]

\section{Sample collection}

Twenty raw milk samples, drawn from bulk milk lots which were positive in the microbiological screening tests, were collected during 2001-2003 and their BP 
concentrations were determined. The samples were stored at $-70^{\circ} \mathrm{C}$ and analysed within two months.

\section{Chemical analysis}

Benzylpenicillin in milk samples was analysed using a multiresidue method detecting also phenoxymethylpenicillin, amoxicillin, ampicillin, oxacillin and cloxacillin. The method was based on the one used for meat products devised by Verdon and Coëdor (1999) and was applied for milk with some modifications. Briefly, the milk samples were centrifuged at $10^{\circ} \mathrm{C}$ for defatting. The sample tubes were kept at $-18^{\circ} \mathrm{C}$ for $10 \mathrm{~min}$ and the fat button was removed with a spatula. The defatted milk samples were transferred with sodium phosphate buffer $(3 \times 5 \mathrm{ml} ; 0.1 \mathrm{M}$ at $\mathrm{pH} 8)$ into ultracentrifuge tubes, ensuring that all of the precipitate on the bottom was transferred. The $\mathrm{pH}$ was adjusted to 8.0-8.1 and the capped tubes were shaken horizontally for $10 \mathrm{~min}$. The samples were clarified by centrifugation $\left(12000 \mathrm{~g}\right.$ for $15 \mathrm{~min}$ at $10^{\circ} \mathrm{C}$ ) and vacuum filtration using glass fibre filters (Millipore). The extracts were further purified with $\mathrm{C} 18$ solid phase extraction (SPE). The eluents were derivatized with benzoic acid anhydride and mercuric chloride, diluted with phosphate buffer $(1: 1 ; 0.1 \mathrm{M} \mathrm{pH} 8)$ and analysed with high performance liquid chromatography (HPLC) using a reversed phase column (Hypersil BDS C18 $5 \mu \mathrm{m} 250 \times 4 \mathrm{~mm}$ Agilent Technologies, Germany) and UV (diode array) detection. The SPE, derivatization and HPLC procedures followed in general the method of Verdon and Coëdor (1999). Positive samples were confirmed with UV spectrum and penicillinase treatment. 
The limit of detection (LOD) was calculated on the basis of a $3: 1 \mathrm{~S} / \mathrm{N}$ ratio from blank milk and standard solution $\left(10 \mu \mathrm{gl}^{-1}\right)$ taking into account correction for the recovery. The limit of quantification (LOQ) was calculated similarly based on a $6: 1 \mathrm{~S} / \mathrm{N}$ ratio. To determine the recovery, blank milk samples were spiked at a level of $10 \mu \mathrm{g} \mathrm{I}^{-1}$ with six replicates. The measurement uncertainty was $3 \%$.

\section{Construction of the simulation model}

The model consisted of five consecutive steps. Three steps described the dilution processes, one step simulated the exposure of fattening pigs and the final step estimated the amount of residues in pork meat and its relation to the MRL-value. The calculations in the five steps were as follows:

Step 1. Residue concentration in dairy silo was calculated by multiplying the respective concentration in truck or trailer (a distribution) with the ratio of the quantity of the milk on truck or trailer (a distribution) to the quantity of milk in silo (a distribution).

Step 2. The concentration in feed was calculated by dividing the concentration in silo (step 1) with the final feed dilution factor (a distribution).

Step 3. Daily exposure of pigs was calculated as the product of concentration in feed (step 2) and quantity of feed fed per day. The total exposure of pigs was calculated as a product of concentration in feed (step 2), quantity of feed fed per day and number of days fed.

Step 4. The maximum amount of residue in $1 \mathrm{~kg}$ of pork was calculated as a product of daily exposure of pigs (step 3 ) and bioavailability, divided by approximate weight of pig carcases. 
Step 5. The maximum amount of residue in $1 \mathrm{~kg}$ of pork (step 4) in relation to the appropriate MRL was calculated as the percentage of the latter.

The input for parameters of the model were given as probability distributions based on observed data points, or as fixed point estimates, i.e. means of the observed data and literature references (see Table 1). The goodness of fit of the observed data with the representative input distributions is given in Table 1 . The model employed Monte-Carlo sampling of the input distributions and the final concentration of the residues in feed was hence also obtained in the form of probability distributions.

\section{[insert Table I about here]}

Each model run consisted of 10000 simulation runs. The simulation model was implemented on commercial spreadsheet software (Excel 2002, Microsoft Corporation, USA), with a commercial Excel add-in module for risk analysis (@Risk, version 4.5.2, Palisade Corporation, USA).

\section{Statistical procedures}

The goodness of fit of the observed data with the employed probabilistic distributions to represent them was tested with Chi square test for the concentration in truck or trailer, and Kolmogorov-Smirnov test for the quantity of milk in truck or trailer, quantity of milk in dairy silo and final feed dilution factor. The $p$-value of the latter three was obtained by Smirnov's chi square 
approximation. The calculations were performed with Statistix for Windows software (Analytical Software, USA).

\section{Results}

$B P$ residues in rejected bulk milk

The LOD and LOQ for benzylpenicillin were determined to be $2 \mu \mathrm{g} \mathrm{I}^{-1}$ and

$4 \mathrm{Mg} \mathrm{l}^{-1}$, respectively. The mean recovery of benzylpenicillin in the recovery study was $113 \%$ and the relative standard deviation was $1.5 \%$.

The average concentration of BP in the analysed bulk milk samples was 16.9 $\mu \mathrm{g} \mathrm{I}^{-1}$ (median $6.9 \mu \mathrm{g} \mathrm{I}^{-1}, 90 \%$ probability interval 2.3-37.9). The distribution of the observed values conformed to Lognormal distribution (@Risk module), with the parameters calculated from the observed data.

[insert Table II about here]

Simulated exposure of pigs to $B P$ residues via feed

On average, each bulk milk lot rejected at the dairy, was diluted 13-fold (median 8.3, $90 \%$ probability interval $1.7-40.7)$ before it was fed to pigs. According to the simulation model, the average BP concentration in feed was $3.1 \mathrm{\mu g} \mathrm{l}^{-1}$ (median $1.2 \mu \mathrm{g} \mathrm{I}^{-1}, 90 \%$ probability interval $0.1-11.9 \mu \mathrm{g} \mathrm{I}^{-1}$ ). Approximately $80 \%$ of the results for the $B P$ residue concentration in feed remained under the MRL of BP $\left(4 \mu \mathrm{g}^{-1}\right)$ set for milk for human consumption (EMEA 2005a) (see Figure 2).

[insert Figure 2 about here] 
According to the model, the average daily exposure of fattening pigs to BP residues was $31.9 \mu \mathrm{g} \mathrm{day}^{-1}$ (median $12.0 \mu \mathrm{g} \mathrm{day}^{-1}$, 90\% probability interval $1.2-$ $119.2 \mu \mathrm{g} \mathrm{day}{ }^{-1}$ ) during the time that they were fed with the feed containing rejected milk. In the current situation, exposure to BP residues at this level continued on average for 3.6 days (maximum of 7 days) resulting in a total exposure to BP residues during the pigs lifetime of an average of $111.0 \mu \mathrm{g}$ (median $42.9 \mu \mathrm{g}, 90 \%$ probability interval $4.5-411 \mu \mathrm{g}$ ).

\section{Possible BP residues in pork}

Only a fraction of the ingested BP in feed is absorbed and BP is quickly eliminated from the body, mainly via urine. Prior to its elimination, the average amount of the orally ingested BP absorbed was $9.3 \mu \mathrm{g} \mathrm{day}^{-1}$. (median 3.6, 90\% probability interval $0.4-34.4 \mu \mathrm{g} \mathrm{day}^{-1}$ ). As the daily feed proportion is broken down into 3-4 meals, the average amount of BP absorbed during each meal varies between 3.1-2.3 $\mu \mathrm{g} / \mathrm{meal}$. The figure 3 demonstrates a feeding schema where pigs are fed 3 times a day. In case of other feeding schemes, such as four meals per day, the exposure per meal is even lower as the proportions diminish when pigs are fed more often. In view of the rapid elimination, accumulation of BP at such low exposure levels is negligible (see Figure 3).

\section{[insert Figure 3 about here]}

Risk estimate for $B P$ 
To assess the potential health risk of $\mathrm{BP}$ residues in pork for humans a risk estimate was created by comparing the maximum concentration of BP in pork and the MRL of BP set for meat. Residue levels in meat below the MRL are considered to be safe for human consumption (EMEA 2005b).

According to the model, the BP concentration in pork would remain well below the MRL: after 3.5 days of feeding, the average total amount of BP in the pigs immediately after the last feeding would be $9.3 \mu \mathrm{g}$ (median $0.4,90 \%$ probability interval 3.6-35.8 $\mu \mathrm{g}$ ), which would be distributed throughout the body, mainly to stomach and duodenum (McKellar et al. 1987). Pork was estimated to contain on average $0.2 \%$ of the MRL concentration (median $0.09 \%, 100 \%$ of the results less than $1 \%)$.

\section{Discussion}

1 The route of the exposure in this study has a novel perspective. If animal by-

2 products are used as animal feed then they still have the possibility of gaining

3 access to the human food chain. Therefore, there is clearly an increased need

4 for realistic assessments of risks involved in the use of animal by-products. In

5 this research we have concentrated on benzylpenicillin as one of the potential

6 hazards involved in the process. Other measured antimicrobials are seldom

7 detected in milk. The half-life of these other measured betalactams is short and

8 they do not bioaccumulate more readily than BP. As other betalactam

9 antimicrobials are better tolerated by consumers than BP, they are not expected

10 to pose a greater risk and are not evaluated in this study. 
1 If BP was deliberately added to feed, a normal withdrawal period should be

2 applied prior to the slaughter. However, if feed contains rejected milk, there is

3 no withdrawal period. Exposed pigs are allowed to be slaughtered immediately

4 and residues of BP may thus occur in meat. Thereafter the exposure of pigs to

5 BP was only evaluated via this route of using dairy by-products as feed.

In order to assess the risk, reliable data on the level of hazard in commodities are needed. The benzylpenicillin analysis method, modified from a method used for muscle samples, worked well for milk. The sample preparation was rather straight-forward and the recovery and relative standard deviation were good in the recovery study. The method has been used in Finland for many years at the EU National Residue Control Program to detect and quantify BP in milk and has been shown to be a reliable method for this purpose, in several proficiency and intercalibration tests it has produced z-scores between \pm 2 .

No MRL for BP residues in feed has been established. However, if the same concentration of BP residues was found in milk as estimated in the pig feed with current practice in Finland, this milk would be approved for human consumption. This study employed probabilistic distributions instead of average point estimates used in many other exposure studies for concentrations and intake values (e.g. Park et al. 2004, Caldas and Souza 2004, Rao et al. 2004). This approach permits a more realistic estimation of the variability in the exposure, and the ensuing residue levels. Risk assessment based on the described variation in the factors is well in line with the transparency objective (Codex Alimentarius Comission [CAC] 1999). 
Based on the model, due to the current practice pork was estimated never to contain over $1 \%$ of the MRL for $\mathrm{BP}$, even if the animals were to be slaughtered immediately after feeding. This level of BP residues in pork is below the detection limits. In normal practice pigs are not fed for several hours before they are slaughtered and therefore due to the active elimination, the actual BP concentration in meat at slaughter would be even lower than estimated. According to our data, pigs are exposed to this type of feed only once during their lifetime. Therefore this exposure can be considered as an acute instead of a continuous exposure.

Instead of using a model to assess the probable distribution of concentration of $\mathrm{BP}$ residues in pork, there is the theoretical possibility of obtaining actual samples of retail pork and performing the chemical analyses. However, the number of samples to confidently detect the residues, the concentration of which most likely would lie below the detection limit of the method, was considered prohibitive.

Usually the safety of the long-term exposure to different compounds found in human diets is evaluated by comparing the estimated intake with acceptable daily intake values (ADI) (Reynolds et al. 2004, Rao et al. 2004, Caldas and Souza 2004), or with no observed adverse effect levels (NOAEL) (Poole et al. 2004). The consumption of pork in Finland was not estimated in this study and therefore the safety estimation was made by comparing the estimated BP residue concentrations in meat with $M R L$. The smallest amount of $B P(3 \mu g)$ 
which has been observed to elicit allergic reactions in previously sensitized individuals would require, according to our model, a consumption of about $25 \mathrm{~kg}$ of pork before any adverse health effects would be expected even in the most sensitive individuals. The Finnish practice of disposing of this dairy by-product as feed can therefore be considered as safe from the residue point of view for pork consumers.

Animal by-products may pose a risk for consumer, if used for animal feeding. Our study has shown that the risk can be vanishingly small and nutritionally valuable feed raw material should not be summarily rejected without a careful assessment of the situation in each case.

\section{References:}

Anderson RM, Donnely CA, Ferguson NM, Woolhouse MEJ, Watt CJ, Udy HJ, MaWhinney S, Dunstan SP, Southwood TRE, Wilesmith JW, Ryan JBM, Hoinville LJ, Hillerton JE, Austin AR, Wells GAH. 1996. Transmission dynamics and epidemiology of BSE in British cattle. Nature 382:779-788.

Borrie P, Barret J. 1961. Dermatitis caused by penicillin in bulked milk supplies. British Medical Journal 2:1267.

CAC 1999. Codex Alimentarius Comission [internet]. Principles and guidelines for the conduct of microbiological risk assessment. CAC/GL-30. Avalilable from: $\quad$ www.codexalimentarius.net/download/standards/357/CXG 030e.pdf. Accessed 2005 October 5. 
Caldas ED, Souza LC. 2004. Chronic dietary risk for pesticide residues in food in Brazil: an update. Food Additives and Contaminants 21:1057-1064.

Dewdney JM, Maes L, Raynaud JP, Blanc F, Scheid JP, Jackson T, Lens S, Verschueren C. 1991. Risk assessment of antibiotic residues of $\beta$-lactams and macrolides in food products with regard to their immuno-allergic potential. Fd. Chem. Toxic 29:447-483.

EU 2002. Commission Regulation (1774/2002). Laying down health rules concerning animal by-products not intended for human consumption. Official Journal of the European Communities L 273:1-95.

EC 1990. Council Regulation 2377/90 laying down a community procedure for the establishment of maximum residue limits of veterinary medical products in foodstuffs of animal origin. Official Journal of the European Communities L224:1-8.

EMEA 2005a. European Medicines Agency [internet]. MRL summary reports on the scientific evaluations carried out by the Committee for Veterinary Medicinal Products (CVMP). Available from: http://www.emea.eu.int/index/indexv1.htm. Accessed 2005 June 22.

EMEA 2005b. European Medicines Agency [internet]. Position paper on the establishment of MRLs for milk considering the daily intake by children. 
Available from: http://www.emea.eu.int/pdfs/vet/press/pp/039102en.pdf. Accessed 2005 June 22.

FAM 2005. Finnish Association for Milk Hygiene [internet]. Residues of antimicrobial drugs in Finnish raw milk. Available from: http://www.maitohygienialiitto.fi/residues_engl.html. Accessed 2005 June 22.

Luthman J, Dall V, Jacobsson SO, Bengtsson B, Korpe C. 1988. Influence of the local tolerance on the pharmacokinetics of two penicillin G preparations in cattle and swine. Acta Veterinaria Scandinavica 29:199-206.

McKellar QA, Baxter P, Taylor D, Bogan JA. 1987. Penicillin therapy of spontaneous streptococcal meningitis in pigs. Veterinary Record 121:347-350.

MMM 2001. Ministry of Agriculture and Forestry. The Finnish legislation on animal diseases K10, (31/EEO/2001). Veterinary and Food Department, Ministry of Agriculture and Forestry, Finland.

NFA 2004. National Food Administration. Survey for the Finnish dairy industry on the production of by-products in 2004. Personal communication.

Park JW, Kim EK, Kim YB. 2004. Estimation of the daily exposure of Koreans to aflatoxin $B_{1}$ through food consumption. Food Additives and Contaminants $21: 70-75$ 
Poole A, Van Herwijnen P, Weideli H, Thomas MC, Ransbotyn G, Vance C. 2004. Review of the toxicology, human exposure and safety assessment for bisphenol A diglycidylether (BADGE). Food Additives and Contaminants 21:905-919.

Plumb DC. 1991. Veterinary drug handbook. (White Bear Lake, MN: PharmaVet Publishing), 470-471.

Rao P, Bhat RV, Sudershan RV, Krishna TP, Naidu N. 2004. Exposure assessment to synthetic food colours of a selected population in Hyderabad, India. Food Additives and Contaminants 21:415-21.

Rantala 2004. Missä painossa siat teuraaksi? (in Finnish). Lihatalous 6:18-19.

Reynolds SL, Hill ARC, Thomas MR, Hamey PY. 2004. Occurrence and risks associated with chlormequat residues in a range of foodstuffs in the UK. Food Additives and Contaminants 21:457-471.

Verdon E, Coëdor P. 1999. Multiresidue analytical method for the determination of eight penicillin antibiotics in muscle tissue by ion-pair reversedphase HPLC after precolumn derivatization. Journal of AOAC International 82:1083-1095.

Wilesmith JW, Wells GAH, Cranwell MP, Ryan JBM. 1988. Bovine spongiform encephalopathy: Epidemiological studies. Veterinary Record 123:638-644. 


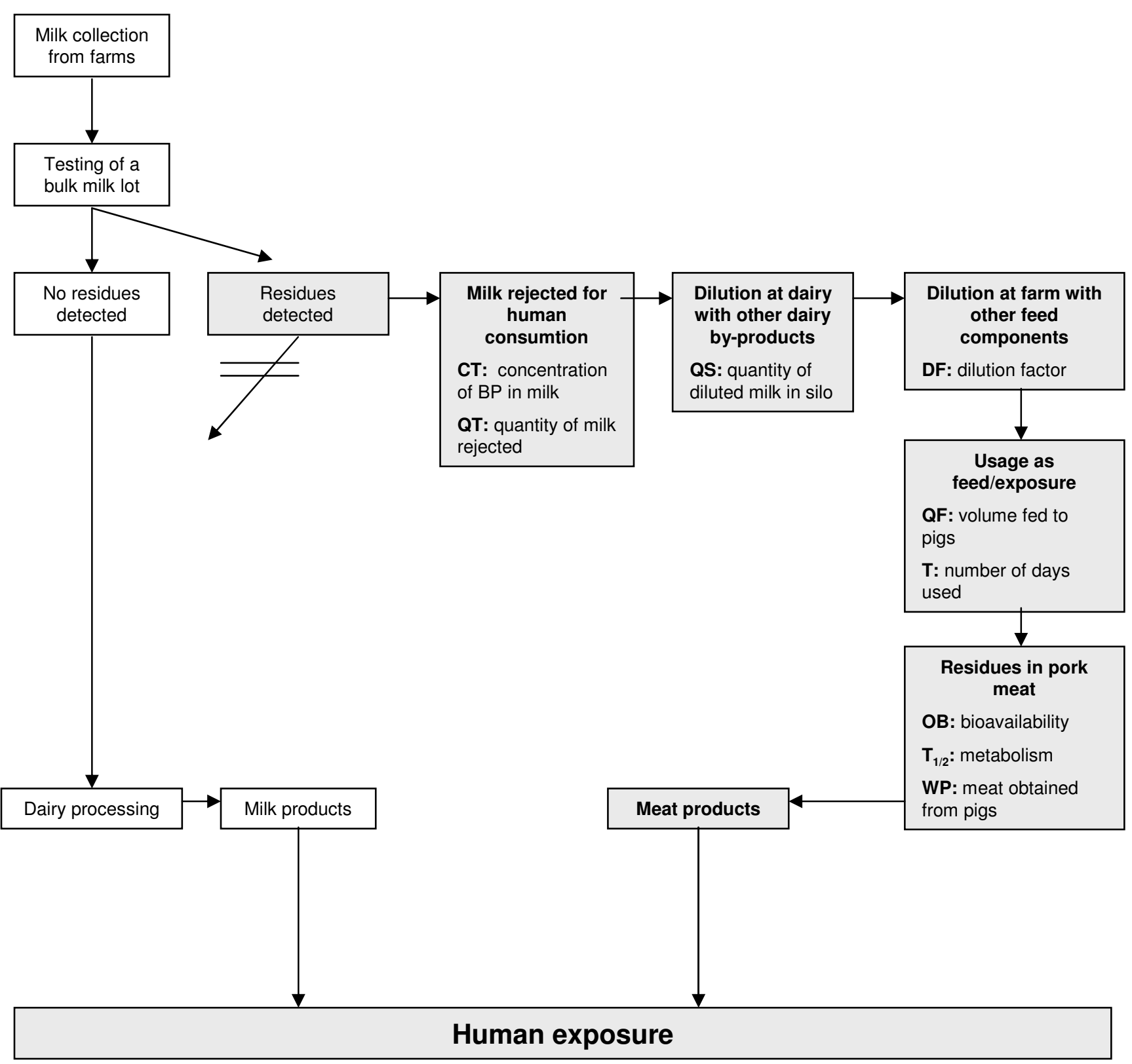




\begin{tabular}{|c|c|c|c|c|}
\hline Step in the model & Inputs & $\begin{array}{l}\text { Symbol in } \\
\text { Figure } 1\end{array}$ & Description & unit \\
\hline \multirow[t]{2}{*}{ STEP 1: Rejected milk lots } & Quantity in transport truck & QT & $\begin{array}{l}\text { Quantity of milk in transport truck } \\
\text { rejected due to a test positive result }\end{array}$ & litres \\
\hline & $\begin{array}{l}\text { BP concentrations } \\
\text { in transport truck }\end{array}$ & CT & $\begin{array}{l}\text { Samples were drawn from the test positive } \\
\text { milk lots and BP concentrations were analysed }\end{array}$ & $\mu g$ litre $^{-1}$ \\
\hline STEP 2: Dilution at dairy & Quantity in dairy silo & QS & $\begin{array}{l}\text { Quantity of rejected milk and other dairy } \\
\text { by-products mixed together in dairy silo }\end{array}$ & litres \\
\hline STEP 3: Dilution at farm & Dilution factor at farms & DF & $\begin{array}{l}\text { A factor indicating the dilution of rejected milk } \\
\text { at farms due to the mixing with other feed components }\end{array}$ & \\
\hline \multirow[t]{2}{*}{ STEP 4: Exposure } & Quantity of feed eaten daily & QF & The total amount of feed fed to the pigs daily & litres day ${ }^{-1}$ \\
\hline & Number of days fed & $\mathrm{T}$ & Duration of time when feed contains rejected milk & days \\
\hline \multirow[t]{4}{*}{ STEP 5: Residues in meat } & Oral bioavailability & OB & Bioavailability of BP when ingested orally & $\%$ \\
\hline & Elimination $t_{1 / 2}$ & $\mathrm{~T}_{1 / 2}$ & Half life of BP & $\mathrm{h}$ \\
\hline & Weight of the pig carcases & WP & $\begin{array}{l}\text { The average amount of meat which is } \\
\text { obtained from each pig at slaughter }\end{array}$ & $\mathrm{kg}$ \\
\hline & MRL for BP in meat & & $\begin{array}{l}\text { The maximum residue limits in meat set by the } \\
\text { European Medicines Agency }\end{array}$ & $\mu \mathrm{kg}^{-1}$ \\
\hline
\end{tabular}

$1 \mathrm{p}$-value: probability of the data given the parametrized distribution 


\begin{tabular}{cll}
\hline $\begin{array}{c}\text { Employed distributions Goodness } \\
\text { of fit of data }\end{array}$ & \multicolumn{1}{c}{ Source of data } & Outputs \\
\hline $\begin{array}{c}\text { Lognorm }(9,911 ; 6,219) \\
\text { Smirnov's chi square } p=0.618^{1}\end{array}$ & National Food Agency & \\
$\begin{array}{c}\text { Lognorm }(16.9 ; 22.8) \\
\text { Chi square } p=0.611^{1}\end{array}$ & Laboratory analyses & \\
$\begin{array}{c}\text { Lognorm(36,380;28,147) } \\
\text { Smirnov's chi square } p=0.443\end{array}$ & National Food Agency & Dilution factor in silo \\
Lognorm(2.56;0.84) & Plant Production Inspection Centre & Concentration in final feed \\
Smirnov's chi square $p=1.000$ & Residue concentration in silo \\
Point estimate:10 & Plant Production Inspection Centre & Daily exposure \\
Point estimate 3.6 & Plant Production Inspection Centre & Total exposure \\
30 & Plump (1991) & The amount of absorbed BP/day \\
1.7 & Luthman et al. (1988) & The amount after elimination (24 h) \\
80 & Rantala (2004) & \% of MRL set for BP in meat \\
50 & EMEA (2005a) & \\
\hline & &
\end{tabular}




\begin{tabular}{cc} 
Sample & $\left.\mathrm{BP}(\mu \mathrm{g} \mathrm{I})^{-1}\right)$ \\
\hline 1 & 29 \\
2 & 65 \\
3 & 4 \\
4 & 10 \\
5 & 6 \\
6 & 6 \\
7 & 9 \\
8 & 24 \\
9 & 14 \\
10 & 17 \\
11 & 6 \\
12 & 8 \\
13 & 3 \\
14 & 6 \\
15 & 92 \\
16 & 22 \\
17 & 0 \\
18 & 5 \\
19 & 6 \\
20 & 5 \\
\hline Average & 16.9 \\
Stdev & 22.8
\end{tabular}

1

2

3

4

5

6

7

10

12

13

14

15

16

17

18

19

20

21

22

23

24

25

26

27

28

29

30

31

32

33

34

35

36

37

38

39

40

41

42

43

44

45

46

47

48

49

50

51

52

53

54

55

56

57

58

59

60

http://mc.manuscriptcentral.com/tfac Email: fac@tandf.co.uk 


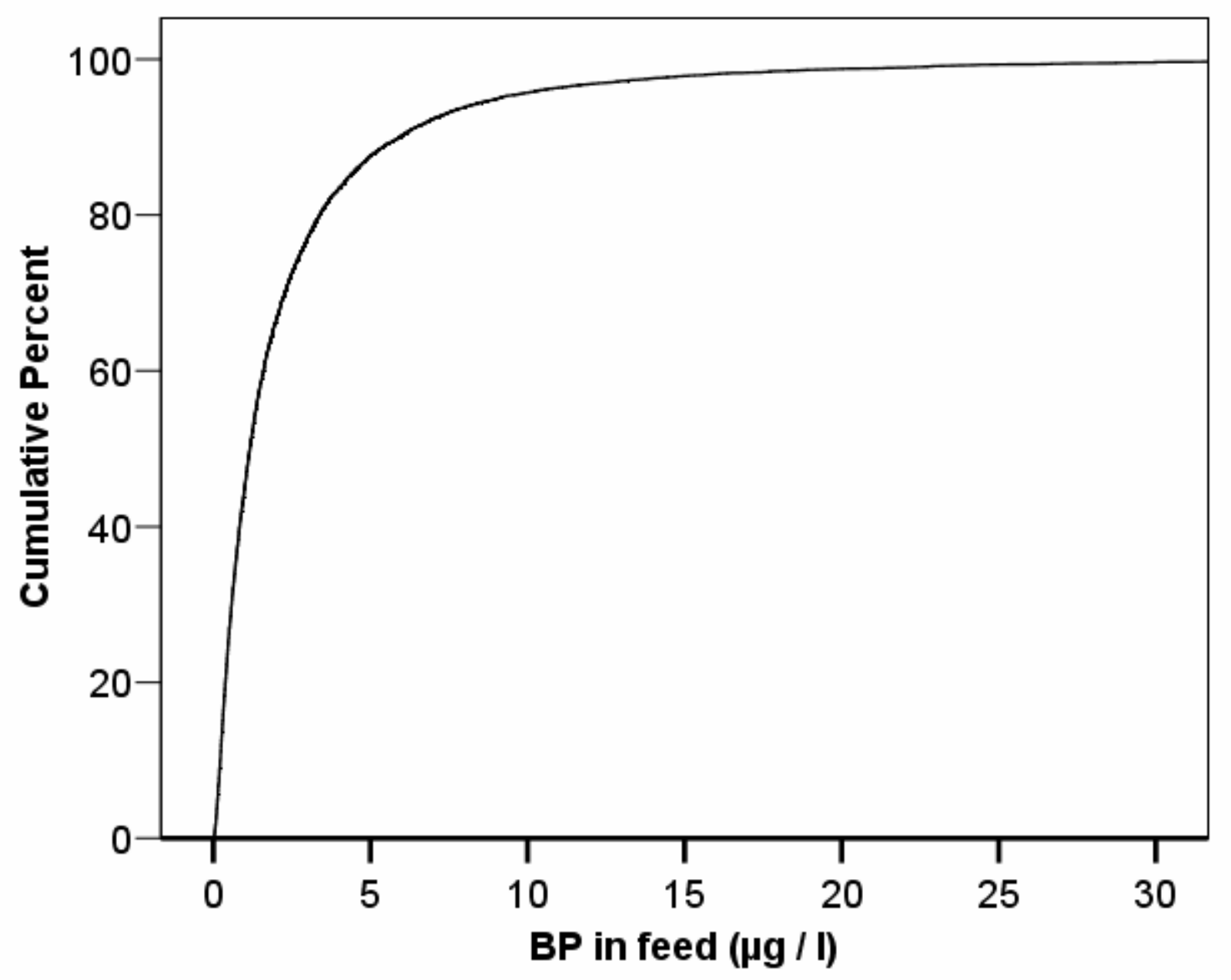

http://mc.manuscriptcentral.com/tfac Email: fac@tandf.co.uk 


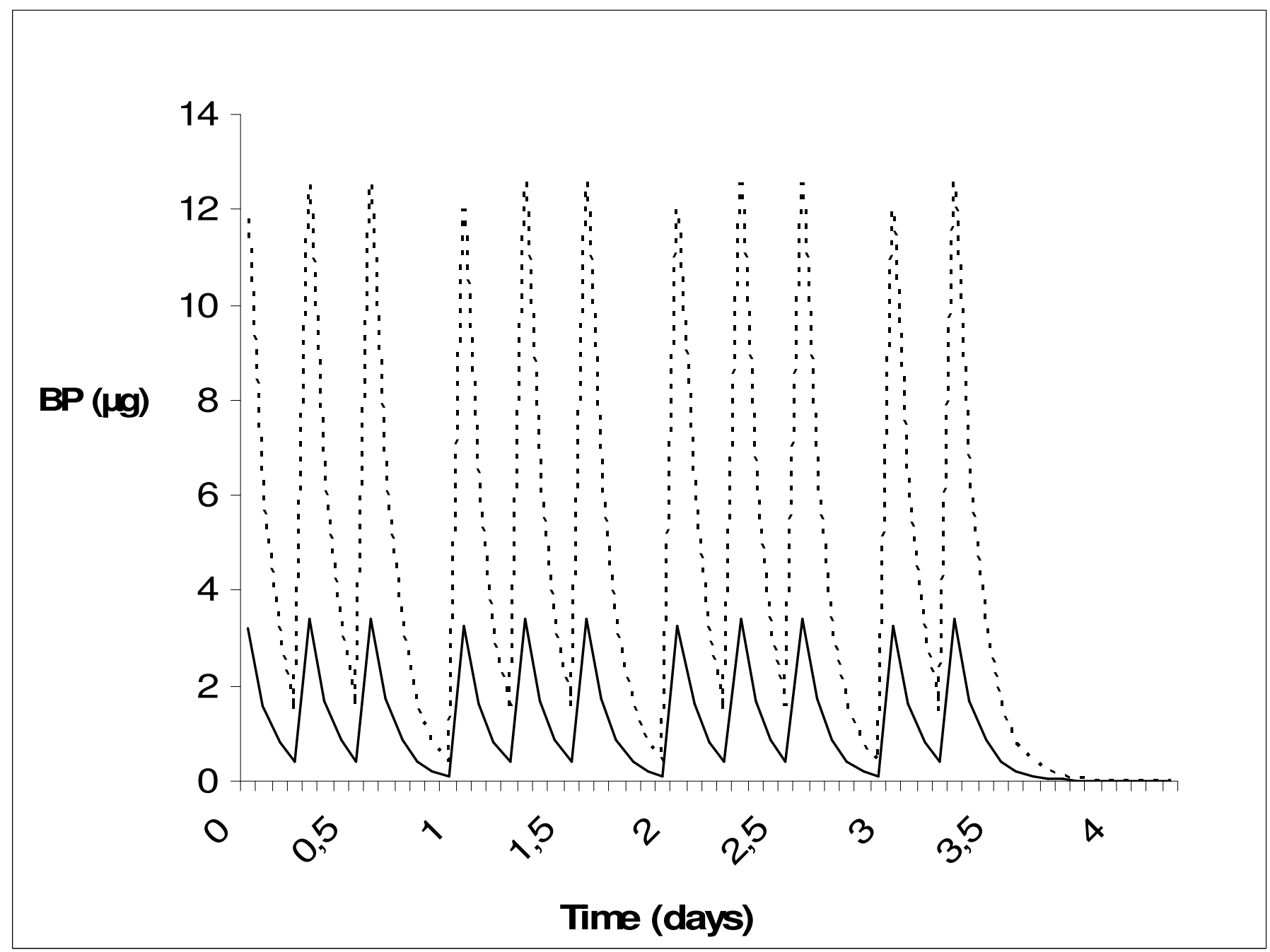

http://mc.manuscriptcentral.com/tfac Email: fac@tandf.co.uk 